\title{
Analysis of Factors Affecting the Performance of Midwife in the Work Area of the Sipiongot Inpatient Health Center
}

\author{
Anni Rizkiyah Ritonga ${ }^{1}$, Asriwati Amirah ${ }^{2}$, Endang Maryanti ${ }^{2}$ \\ ${ }^{1}$ Master's Program in Public Health, Helvetia Institute of Health, Indonesia \\ ${ }^{2}$ Lecturer of Master Program Faculty of Public Health, Helvetia Institute of Health Medan, \\ Indonesia \\ Received: October 28, 2021 \\ Received in Revised: December 1, 2021 \\ Accepted: December 7, 2021
}

\begin{abstract}
This study aims to analyze the factors that influence the performance of midwives in the work area of the Sipiongot Inpatient Health Center, Dolok District, North Padang Lawas Regency. This type of research is an analytic survey with a transverse surgical approach. Sampling used a total sampling technique, namely all midwives in the Sipiongot Inpatient Health Center Work Area as many as 69 Midwives. The results showed that the majority of midwives' performance was included in the poor category, namely 39 people $(56.5 \%)$, the majority of midwives' abilities were included in the capable category, namely 51 people $(73.9 \%)$, the majority of midwives' knowledge was included in the good category, namely as much as 46 people (66.7\%), the majority of midwives' skills were included in the bad category as many as 39 people $(56.5 \%)$ and the majority of midwives' leadership were included in the bad category, namely 35 people $(50.7 \%)$. There is a relationship between ability [p $(\mathrm{sig})=0.017$, knowledge $[p($ sig $)=0.000]$, skills [p (sig) $=0.029]$ and leadership [p (sig) $=0.022]$ on the performance of midwives in the working area of the Outpatient Health Center. Sipiongot Inpatient, Dolok District, North Padang Lawas Regency in 2021. The most dominant variable affecting the performance of midwives is knowledge. It is recommended that midwives in the working area of the Sipiongot Inpatient Health Center improve their performance so that they become professional midwives according to their competencies.
\end{abstract}

Keywords: Midwife Performance, Ability, Knowledge, Skills, Leadership

\section{Introduction}

One way to reduce MMR in Indonesia is to improve the quality of health services, especially examinations of pregnant women by professionals in accordance with ANC service standards, namely weighing, measuring blood pressure, measuring uterine fundus height, tetanus toxoid immunization, giving tablets. adding blood, testing for infectious diseases, and ending with a teleconference in preparation for referrals (Anggraini et al., 2020). The Ministry of Health is determined to shift deliveries at home to deliveries by health workers in health care facilities as an effort to reduce maternal and newborn mortality. The purpose of the delivery program by health workers in health care facilities is to accelerate the access of mothers and newborns in obtaining adequate treatment in the event of an emergency situation for maternity or newborns. The results of the 2017 IDHS show that 79 percent of mothers in Indonesia have given birth with health workers in health care facilities, there is still a gap between urban areas $(91 \%)$ compared to rural areas $(68 \%)$ (Niu, 2017).

The proportion of health workers who provide antenatal care services by province and characteristics can be seen in the 2013 Riskesdas book. Communities with characteristics living in rural areas, low education and being in the lowest to middle ownership index quintiles tend

Copyright @ 2021, Journal of Asian Multicultural Research for Medical and Health Science Study, Under the license CC BY-SA 4.0 
to choose midwives when conducting prenatal check-ups. In contrast, obstetrics and gynecology specialists are chosen by people in urban areas, higher education and the top quintile of ownership index.

The Community Health Center (Puskesmas) as the spearhead of the national health service system, is currently almost helpless and bloodless. This is due to, among others, the lack of resource support in terms of quantity and quality, the lack of operational funds and limited programs for drugs, medical devices and other supporting facilities, both in type and quantity, as well as weak guidance, coaching, and facilitation from district/city health offices and local governments. Since the enactment of the law on compulsory undergraduate work and budget constraints, the Indonesian Ministry of Health has had difficulty recruiting and placing doctors and dentists in puskesmas (Satrianegara, 2014).

Puskesmas have the task of implementing health policies to achieve health development goals in their working areas in order to support the realization of a healthy sub-district. In addition to carrying out these tasks, the puskesmas has a function as the organizer of the first level of Public Health Efforts (UKM) and the first level of Individual Health Efforts (UKP) as well as a vehicle for education of health workers. Public health efforts are every activity to maintain and improve health as well as prevent and overcome health problems with the target of families, groups and communities. Individual health effort is an activity and/or a series of health service activities aimed at improving, preventing, curing disease, reducing suffering due to disease and restoring individual health. According to Satrianegara, (2014) Puskesmas (Community Health Center) should provide comprehensive and integrated health services to the community, where the services provided include levels of promotive, preventive, curative and rehabilitative services.

The role of Human Resources, in this case the midwife, is a determinant for the success of health services carried out in an organizational institution, namely the Puskesmas. Midwives as human resources who carry out activities at puskesmas are influenced by various things, both internal factors or individual characteristics (internal) and work environment factors or characteristics of workers and organizations (external). Likewise with performance, performance is a result achieved by a person in carrying out the tasks assigned to him based on his abilities, skills, experience and abilities and time. Good quality workers not only turn the palm of the hand but it must be done with hard work and high discipline, both in the long term and in the short term (Wibowo, 2014).

\section{Methods}

The research design used in this study was an analytical survey with a cross-sectional (crosssectional) surgical approach. The purpose of this study is to analyze the factors that influence the performance of midwives in the work area of the Sipiongot Inpatient Health Center, Dolok District, Padang Lawas Regency. The population in this study were all midwives in the Sipiongot Inpatient Health Center working area as many as 69 midwives. The sample in this study was the total population, namely all midwives in the Sipiongot Inpatient Health Center working area as many as 69 midwives.

\section{Results and Discussion}

\section{Respondents Characteristics}

Table 1. Frequency Distribution of Respondents Based on Characteristics in the Working Area of the Sipiongot Inpatient Health Center in 2021

\begin{tabular}{|l|l|l|} 
Characteristics of respondents & Sum & Percentage \\
\hline
\end{tabular}




\begin{tabular}{|c|c|c|}
\hline $\begin{array}{l}\text { 1. Age } \\
1.25-35 \\
2.36-58 \\
\end{array}$ & $\begin{array}{l}43 \\
26 \\
\end{array}$ & $\begin{array}{r}62,3 \\
37,7 \\
\end{array}$ \\
\hline Sum & 69 & 100 \\
\hline $\begin{array}{l}\text { 2. Education } \\
\text { 1. DIII } \\
\text { 2. YES }\end{array}$ & $\begin{array}{l}58 \\
11\end{array}$ & $\begin{array}{l}84,8 \\
15,9\end{array}$ \\
\hline Sum & 69 & 100 \\
\hline $\begin{array}{l}\text { 3. Working time } \\
\text { 1. 1-10 Years } \\
\text { 2. 11-20 Years }\end{array}$ & $\begin{array}{l}30 \\
39 \\
\end{array}$ & $\begin{array}{l}43,5 \\
56,5 \\
\end{array}$ \\
\hline Sum & 69 & 100 \\
\hline
\end{tabular}

Based on the table above, it can be seen that the frequency distribution of respondents based on characteristics (age, education, and tenure) includes, among others, that the results of the study indicate that the majority of respondents are in the age range of 25-40 years as many as 43 people $(62.3 \%)$. The age minority is 26 people (37.6\%). In the education category, most of the midwives in the working area of the Sipiongot Inpatient Health Center with the DIII education category are 58 people $(84.8 \%)$ and the SI education are 11 people $(15.9 \%)$. In the category of working period, most of the midwives in the working area of the Sipiongot Inpatient Health Center with the category of working period of 1-10 years were 39 people $(56.5 \%)$. And working period of $11-20$ years $(56.6 \%)$.

\section{Midwife Performance}

The frequency distribution of midwife performance variables in the working area of the Sipiongot Inpatient Health Center, Dolok District, North Padang Lawas Regency in 2021 can be seen in the following table:

Table 2. Frequency Distribution of Midwife Performance

\begin{tabular}{|c|c|c|}
\hline Midwife Performance & Sum & Percentage \\
\hline Good & 30 & 43,5 \\
\hline Less Good & 39 & 56,5 \\
\hline Sum & 69 & 100 \\
\hline
\end{tabular}

Source: Primary Data (processed) 2021

Based on table 2. it can be seen that the majority of midwives' performance is included in the poor category, namely 39 people $(56.5 \%)$, while the rest are included in the good category, namely 30 people $(43.5 \%)$.

\section{Ability}

The frequency distribution of the variable ability of midwives in the working area of the Sipiongot Inpatient Health Center, Dolok District, North Padang Lawas Regency in 2021 can be seen in the following table:

Table 3. Ability Frequency Distribution

\begin{tabular}{|c|c|c|}
\hline Ability & Sum & Percentage \\
\hline Can & 51 & 73,9 \\
\hline Underprivileged & 18 & 26,1 \\
\hline Sum & 69 & 100 \\
\hline
\end{tabular}

Source: Primary Data (processed) 2021 
Based on table 3. it can be seen that the majority of midwives' abilities are included in the capable category, namely 51 people $(73.9 \%)$, while the rest are included in the poor category as many as 18 people $(26.1 \%)$.

\section{Knowledge}

The frequency distribution of the knowledge variable of midwives in the working area of the Sipiongot Inpatient Health Center, Dolok District, North Padang Lawas Regency in 2021 can be seen in the following table:

Table 4. Knowledge Frequency Distribution

\begin{tabular}{|lc|c|c|}
\hline \multicolumn{2}{|c|}{ Knowledge } & Sum & Percentage \\
\hline Good & & 46 & 66,7 \\
Bad & & 23 & 33,3 \\
\hline \multicolumn{2}{|c|}{ Sum } & $\mathbf{6 9}$ & $\mathbf{1 0 0}$ \\
\hline
\end{tabular}

Source: Primary Data (processed) 2021

Based on table 4. it can be seen that the majority of midwives' knowledge was included in the good category, namely 46 people $(66.7 \%)$, while the rest were included in the bad category, namely 23 people (33.3\%).

\section{Skills}

The frequency distribution of the midwife skill variable in the working area of the Sipiongot Inpatient Health Center, Dolok District, North Padang Lawas Regency in 2021 can be seen in the following table:

Table 5. Skill Frequency Distribution

\begin{tabular}{|l|c|c|}
\hline \multicolumn{1}{|c|}{ Skills } & Sum & Percentage \\
\hline Good & 30 & 43,5 \\
Bad & 39 & 56,5 \\
\hline \multicolumn{1}{|c|}{ Sum } & $\mathbf{6 9}$ & $\mathbf{1 0 0}$ \\
\hline
\end{tabular}

Source: Primary Data (processed) 2021

Based on table 4.4. it can be seen that the majority of midwives' skills are included in the bad category as many as 39 people $(56.5 \%)$, while the rest are included in the good category as many as 30 people (43.5\%).

\section{Leadership}

The frequency distribution of the midwife leadership variable in the working area of the Sipiongot Inpatient Health Center, Dolok District, North Padang Lawas Regency in 2021 can be seen in the following table:

Table 6. Distribution of Leadership Frequency

\begin{tabular}{|lc|c|c|}
\hline \multicolumn{2}{|c|}{ Leadership } & Sum & Percentage \\
\hline Good & 34 & 49,3 \\
Bad & 35 & 50,7 \\
\hline \multicolumn{2}{|c|}{ Sum } & $\mathbf{6 9}$ & $\mathbf{1 0 0}$ \\
\hline
\end{tabular}

Source: Primary Data (processed) 2021 
Based on table 5. it can be seen that the majority of midwives' leadership included in the bad category as many as 35 people $(50.7 \%)$, while the rest were included in the good category as many as 34 people $(49.3 \%)$.

\section{Bivariate Analysis}

Bivariate analysis was conducted to determine the relationship between each independent variable or independent variable, namely ability, knowledge, skills and leadership with the dependent variable or the dependent variable, namely the performance of the midwife through crosstable or cross tabulation. Statistical tests were carried out in this bivariate analysis using the chi square test with a $95 \%$ confidence degree $(\alpha=0.05)$.

\section{The Effect of Ability on Midwife Performance in the Working Area of Sipiongot Inpatient Health Center, Dolok District, North Padang Lawas Regency in 2021}

The frequency distribution of the ability relationship to the performance of midwives in the work area of the Sipiongot Inpatient Health Center, Dolok District, North Padang Lawas Regency in 2021 can be seen in the following table:

Table 7. Cross Tabulation between Ability and Performance of Midwives

\begin{tabular}{|c|c|c|c|c|c|c|c|}
\hline \multirow[t]{3}{*}{ Ability } & \multicolumn{6}{|c|}{ Midwife Performance } & \multirow{3}{*}{$\begin{array}{c}p \\
\text { (value) }\end{array}$} \\
\hline & \multicolumn{2}{|c|}{ Good } & \multicolumn{2}{|c|}{ Less Good } & \multicolumn{2}{|c|}{ Sum } & \\
\hline & $\mathbf{F}$ & $\%$ & $\mathbf{F}$ & $\%$ & $\mathbf{F}$ & $\%$ & \\
\hline Can & 27 & 39,1 & 24 & 34,8 & 51 & 73,9 & $\mathbf{0 , 0 1 7}$ \\
\hline Underprivileged & 3 & 4,4 & 15 & 21,7 & 18 & 26,1 & \\
\hline Sum & 30 & & 39 & & 69 & & \\
\hline
\end{tabular}

Source: Primary Data (processed) 2021

Based on table 7, it can be seen that from 69 respondents (100\%) there are 51 midwives who have the ability included in the category capable of the majority with good performance, as many as 27 respondents $(39.1 \%$ ), while 18 midwives have the ability included in the poor category. able majority with poor performance as many as 15 respondents $(21.7 \%)$. Statistical test results obtained $\mathrm{p}$ value $(\mathrm{sig})=0.017(\rho$ value $<0.05)$. This shows that there is a statistically significant or significant relationship between ability and performance of midwives in the working area of the Sipiongot Inpatient Health Center, Dolok District, North Padang Lawas Regency in 2021.

Relationship between Knowledge and Performance of Midwives in the Working Area of the Sipiongot Inpatient Health Center, Dolok District, North Padang Lawas Regency in 2021

The distribution of the frequency of the relationship between knowledge and the performance of midwives in the working area of the Sipiongot Inpatient Health Center, Dolok District, North Padang Lawas Regency in 2021 can be seen in the following table:

Table 8. Cross-tabulation between Knowledge and Midwife Performance

\begin{tabular}{|l|c|c|c|c|c|c|c|}
\hline \multirow{3}{*}{ Knowledge } & \multicolumn{6}{|c|}{ Midwife Performance } & \multirow{2}{*}{$\begin{array}{c}\boldsymbol{p} \\
\text { (value) }\end{array}$} \\
\cline { 2 - 7 } & \multicolumn{2}{|c|}{ Good } & \multicolumn{2}{|c|}{ Less Good } & \multicolumn{2}{c|}{ Sum } & \\
\cline { 2 - 7 } & f & \% & F & \% & F & \% & \\
\hline Good & 29 & 42,0 & 17 & 24,7 & 46 & 66,7 & $\mathbf{0 , 0 0 0}$ \\
Bad & 1 & 1,4 & 22 & 31,9 & 23 & 33,3 & \\
\hline \multicolumn{1}{|c|}{ Sum } & $\mathbf{3 0}$ & & $\mathbf{3 9}$ & & $\mathbf{6 9}$ & & \\
\hline
\end{tabular}

Source: Primary Data (processed) 2021 
Based on table 8, it can be seen that of the 69 respondents (100\%) there are 46 midwives with good knowledge, the majority with good performance, as many as 29 respondents $(42.0 \%)$, while 23 midwives with poor knowledge, the majority with poor performance, namely as many as 22 respondents $(31.9 \%)$. Statistical test results obtained $p$ value $(\mathrm{sig})=0.000(\rho$ value $<0.05)$. This shows that there is a statistically significant or significant relationship between knowledge and performance of midwives in the working area of the Sipiongot Inpatient Health Center, Dolok District, North Padang Lawas Regency in 2021.

\section{Relationship between Skills and Performance of Midwives in the Work Area of the Sipiongot Inpatient Health Center, Dolok District, North Padang Lawas Regency in 2021}

The distribution of the frequency of the relationship between skills and the performance of midwives in the working area of the Sipiongot Inpatient Health Center, Dolok District, North Padang Lawas Regency in 2021 can be seen in the following table:

Table 9. Cross-Tabulation between Skills with midwife performance

\begin{tabular}{|c|c|c|c|c|c|c|c|}
\hline \multirow[t]{3}{*}{ Skills } & \multicolumn{6}{|c|}{ Midwife Performance } & \multirow{3}{*}{$\begin{array}{c}p \\
\text { (value) }\end{array}$} \\
\hline & \multicolumn{2}{|c|}{ Good } & \multicolumn{2}{|c|}{ Less Good } & \multicolumn{2}{|c|}{ Sum } & \\
\hline & $\mathbf{f}$ & $\%$ & $\mathbf{F}$ & $\%$ & $\mathbf{F}$ & $\%$ & \\
\hline Good & 18 & 26,1 & 12 & 17,4 & 30 & 43,5 & $\mathbf{0 , 0 2 9}$ \\
\hline $\mathrm{Bad}$ & 12 & 17,4 & 27 & 39,1 & 39 & 56,5 & \\
\hline Sum & 30 & & 39 & & 69 & & \\
\hline
\end{tabular}

Source: Primary Data (processed) 2021

Based on table 9, it can be seen that from 69 respondents (100\%) there were 30 midwives who had skills included in the good category, the majority with good performance, namely 18 respondents $(26.1 \%)$, while 39 midwives who had skills included in the majority category is not good with poor performance as many as 27 respondents (39.1\%). Statistical test results obtained $p$ value $(\mathrm{sig})=0.029$ ( $\rho$ value $<0.05)$. This shows that there is a statistically significant or significant relationship between skills and the performance of midwives in the working area of the Sipiongot Inpatient Health Center, Dolok District, North Padang Lawas Regency in 2021.

\section{Leadership Relationship to Midwife Performance in the Working Area of Sipiongot Inpatient Health Center, Dolok District, North Padang Lawas Regency in 2021}

The distribution of the frequency of leadership relationships on the performance of midwives in the working area of the Sipiongot Inpatient Health Center, Dolok District, North Padang Lawas Regency in 2021 can be seen in the following table:

Table 10. Cross Tabulation between Leadership and midwifery performance

\begin{tabular}{|l|c|c|c|c|c|c|c|}
\hline \multirow{3}{*}{ Leadership } & \multicolumn{6}{|c|}{ Midwife Performance } & \multirow{2}{*}{$\begin{array}{c}\boldsymbol{p} \\
\text { (value) }\end{array}$} \\
\cline { 2 - 8 } & \multicolumn{2}{|c|}{ Good } & \multicolumn{2}{c|}{ Less Good } & \multicolumn{2}{c|}{ Sum } & \\
\cline { 2 - 7 } & f & \% & F & \% & F & \% & \\
\hline Good & 20 & 29,0 & 14 & 20,3 & 34 & 49,3 & $\mathbf{0 , 0 2 2}$ \\
Bad Sum & 10 & 14,5 & 25 & 36,2 & 35 & 50,7 & \\
\hline \multicolumn{2}{|c|}{ Su } & & $\mathbf{3 9}$ & & $\mathbf{6 9}$ & & \\
\hline
\end{tabular}

Source: Primary Data (processed) 2021

Based on table 10, it can be seen that from 69 respondents (100\%) there were 34 midwives with leadership included in the good category, the majority with good performance, namely 20 respondents (29.0\%), while 35 midwives with leadership were included in the poor category. 
good majority with poor performance as many as 25 respondents (36.2\%). Statistical test results obtained $\mathrm{p}$ value $(\mathrm{sig})=0.022(\rho$ value $<0.05)$. This shows that there is a statistically significant or significant relationship between leadership and the performance of midwives in the working area of the Sipiongot Inpatient Health Center, Dolok District, North Padang Lawas Regency in 2021.

\section{Multivariate Analysis}

Multivariate analysis in this study used multiple logistic regression test. The logistic regression analysis step is carried out in 2 (two) stages, namely the first stage (enter method) to determine the independent variable that has a significance level (sig.) or value $<0.25$, and the second stage (forward method: conditional). The results of the first stage of analysis (enter method) can be seen in the following table:

Table 11. First Stage Multivariate Analysis (Enter Method)

\begin{tabular}{|c|c|c|c|c|c|c|c|}
\hline & B & S.E. & Forest & Df & Itself. & $\operatorname{Exp}(B)$ \\
\hline \multirow{5}{*}{$\begin{array}{l}\text { Step } \\
1^{\mathrm{a}}\end{array}$} & Ability (1) & -1.089 & .828 & 1.731 & 1 & .188 & .336 \\
\hline & Knowledge(1) & -3.169 & 1.097 & 8.350 & 1 & .004 & .042 \\
\hline & Skills(1) & -.635 & .635 & 1.001 & 1 & .317 & .530 \\
\hline & Leadership(1) & -.892 & .633 & 1.985 & 1 & .159 & .410 \\
\hline & Constant & 1.429 & .538 & 7.043 & 1 & .008 & 4.174 \\
\hline
\end{tabular}

Source: Primary Data (processed) 2021

Based on the results of the output (variables in the equation) in the first stage, it can be seen that the variable which has a sig value. $<0.25$ is the ability variable $(0.188)$, knowledge variable (0.004) and leadership variable (0.159). While the skill variable has a value of sig. $>0.25$ which is 0.317 so that the skill variable is not eligible to enter the next multivariate test model. The next step is to include the variables of ability, knowledge and leadership in the second stage of logistic regression (forward: conditional method).

The results of the second stage of analysis can be seen in the following table:

Table 12. Second Stage Multivariate Analysis (Forward Method: Conditional)

\begin{tabular}{|c|c|c|c|c|c|c|c|}
\hline & B & S.E. & Wald & Df & Sig. & $\operatorname{Exp}(B)$ \\
\hline \multirow{2}{*}{$\begin{array}{l}\text { Step } \\
1^{\mathrm{a}}\end{array}$} & Knowledge(1) & -3.625 & 1.067 & 11.540 & 1 & .001 & .027 \\
\hline & Constant & .534 & .305 & 3.057 & 1 & .080 & 1.706 \\
\hline
\end{tabular}

Source: Primary Data (processed) 2021

Based on the output results shown in table 12, (variables in the equation) the second stage can be seen that only the knowledge variable affects the performance of midwives in the Sipiongot Inpatient Health Center Work Area, Dolok District, North Padang Lawas Regency in 2021 with a sig value. $0.001<0.05$ with an $\operatorname{Exp}(\mathrm{B})$ value or an odd ratio of 0.027 . To see the ability of the independent variable in explaining the dependent variable, the Cox \& Snell R Square and Nagelkerke R Square values are used in the following model summary table:

Table 13. Summary Model Analysis of Factors Affecting Midwife Performance in the Working Area of Sipiongot Inpatient Health Center, Dolok District, North Padang Lawas Regency in 2021

\begin{tabular}{|l|c|c|c|}
\hline Step & -2 Log likelihood & Cox \& Snell R Square & Nagelkerke R Square \\
\hline 1 & $68.829^{\mathrm{a}}$ & .310 & .416 \\
\hline
\end{tabular}

Copyright @ 2021, Journal of Asian Multicultural Research for Medical and Health Science Study, Under the license CC BY-SA 4.0 


\section{Source: Primary Data (processed) 2021}

Based on the output results above, the Nagelkerke R Square value is 0.416 and the Cox \& Snell $\mathrm{R}$ Square value is 0.310 , which indicates that the ability of the knowledge variable to explain the performance variable of the midwife is 0.416 or $41.6 \%$.

Based on the Multivariate Analysis that has been carried out, it can be concluded that all variables that enter the model or who pass the candidate selection, have an influence on the performance variable of the midwife (dependent), namely the ability variable, knowledge variable and leadership variable but the most dominant variables affect the performance of the midwife. in the Working Area of the Sipiongot Inpatient Health Center, Dolok District, North Padang Lawas Regency in 2021 is the knowledge variable.

Knowledge is a result of desire through sensory processes, especially in the eyes and ears for certain objects. At the time of sensing to produce knowledge is strongly influenced by the intensity of attention perception of the object. Purwoastuti \& Walyani (2015) stated that A person who has a good level of knowledge about his job will make it easier for him to do his job, while someone who has a poor level of knowledge about his job will make it difficult for him to do his job, which in turn will reduce the quality of his work which will ultimately affect his performance.

The midwifery profession is a noble profession that is intellectual in nature based on science that requires special skills. The midwife profession requires training and mastery of a special knowledge. Therefore, the knowledge of a person who works as a midwife must continue to be developed so that it can support its duties in meeting the demands/needs of a very dynamic society and the development of science and technology.

From the results of respondents' answers, it can be seen that the highest score on the skills questionnaire is for statement item number 1, namely the leader gives permission to the midwife to attend training. This statement implies the importance of support from the leadership, in this case the head of the puskesmas or the coordinating midwife, to contribute more in providing support or stimulation so that the performance of the midwife will be better. Skilled midwives will try to develop and improve their performance and they will try to give the best results in their work, so that the goals that have been set can be achieved, otherwise unskilled midwives will not try to give the best results.

Skills are strengths from within a person that can direct that person's behavior. Pro and positive behavior towards the work situation that strengthens his work skills to achieve maximum performance (Griffin et al., 2007). A permit or a sign of appreciation from the leadership will motivate the midwife to take part in the existing trainings so that she can eventually become a professional midwife.

From the results of respondents' answers, it can be seen that the lowest score on the leadership questionnaire question is for statement item number 10, namely midwives whose performance is good get praise from the leadership. If it is associated with the performance of the midwife, it means that the praise given by the leadership will spur the midwife to achieve higher work performance. Of course, giving praise must adjust the conditions (not excessive). Leaders who behave pleasantly, protect, educate and guide will certainly make the people they lead feel happy and follow what the leader tells them to do, this will certainly improve performance, and vice versa.

Good leadership in an organization which in this case is the leader at the Sipiongot Inpatient Health Center, Dolok District, North Padang Lawas Regency, of course, can regulate, manage and provide direction to midwives in the work area of the Sipiongot Inpatient Health Center 
wisely to carry out maternal and reproductive health services for women. ; family planning services; infant and child health services; and public health services. In evaluating the performance of human resources at the puskesmas, the leadership holds the highest position so that it is responsible for whether or not the performance of the puskesmas is good. Midwives as technical implementers in the field of midwifery services at health service facilities must be able to provide professional services that are an integral part of health services, which are provided to mothers during the reproductive period, newborns, infants, and toddlers.

The development of midwifery services is in line with the progress of obstetrics and gynecology services (Marshall et al., 2012). Midwives as a profession that continues to grow, always maintain their professionalism by following the development of science and technology (Ross et al., 2013). Professionalism is closely related to the competencies that must be possessed by a professional (professional competence). Professional midwives in question must have clinical competence (midwifery skills), socio-cultural skills to analyze, advocate and empower in finding solutions and innovations as an effort to improve the welfare of women, families and communities.

\section{Conclusion}

After doing research on the factors that affect the performance of midwives in the Work Area of the Sipiongot Inpatient Health Center, Dolok District, North Padang Lawas Regency, it can be concluded as follows, There is an influence of ability, knowledge, skills, leadership on the performance of midwives in the work area of the Sipiongot Inpatient Health Center, Dolok District North Padang Lawas Regency. The most dominant variable affecting the performance of midwives in the Work Area of the Sipiongot Inpatient Health Center, Dolok District, North Padang Lawas Regency in 2021 is the knowledge variable with a value of sig < 0.05 , which is 0.001 .

\section{Suggestion}

In an effort to improve the performance of midwives in the working area of the Sipiongot Inpatient Health Center, Dolok District, North Padang Lawas Regency, it is recommended to be more active in making training and seminars for midwives, especially for midwives in the work area of the Sipiongot Inpatient Health Center, Dolok District to improve the performance of midwives so that later they do not feel left behind in terms of science and technology

\section{References}

Anggraini, D. D., Sari, M. H. N., Ritonga, F., Yuliani, M., Wahyuni, W., Amalia, R., ... \& Winarso, S. P. (2020). Konsep Kebidanan. Yayasan Kita Menulis.

Griffin, M. A., Neal, A., \& Parker, S. K. (2007). A new model of work role performance: Positive behavior in uncertain and interdependent contexts. Academy of management journal, 50(2), 327-347.

Marshall, N., Egan, S., Flores, C., Kirsch, A., Mankoff, R., \& Resnick, M. (2012). Working toward a common goal: a collaborative obstetrics and gynecology practice. Obstetrics and Gynecology Clinics, 39(3), 373-382.

Niu F. (2017). Konsep Kebidanan. Jakarta: Cv. Trans Info Media

Purwoastuti E, \& Walyani E.S. (2015). konsep kebidanan. 1st ed. Yogyakarta: Pustaka Baru Press

Ross, K., Barr, J., \& Stevens, J. (2013). Mandatory continuing professional development requirements: what does this mean for Australian nurses. BMC nursing, 12(1), 1-7. 
Satrianegara, M. F. (2014). Organisasi dan Manajemen Pelayanan Kesehatan: Teori dan Aplikasinya dalam Pelayanan Puskesmas dan Rumah Sakit. repositori.uinalauddin.ac.id

Wibowo. (2014). Manajemen Kinerja. Jakarta: PT Grafindo persada 